\title{
Influence of partial substitution of dietary fish meal on the activity of digestive enzymes in the intestinal brush border membrane of gilthead sea bream, Sparus aurata and goldfish, Carassius auratus
}

\author{
Flávia C. P. Silva ${ }^{1}$; Jacques R. Nicoli ${ }^{1}$; José L. Zambonino-Infante ${ }^{2}$; \\ Marie-Madeleine Le Gall ${ }^{2}$, Sadasivam Kaushik ${ }^{3}$; François-Joël Gatesoupe ${ }^{2 \star}$
}

\author{
1 Departamento de Microbiologia, Instituto de Ciências Biológicas, Universidade Federal de Minas \\ Gerais, Belo Horizonte, MG, Brazil. \\ 2 Ifremer, Nutrition Aquaculture et Génomique UMR1067, F-29280 Plouzané, France. \\ 3 INRA, Nutrition Aquaculture et Génomique UMR1067, F-64310 St Pée Sur Nivelle, France.
}

*Corresponding author: Tel.: + 332982243 89; fax: + 332982246 53; e-mail:

joel.gatesoupe@ifremer.fr.

\begin{abstract}
:
The sustainable composition of diets of high nutritional value is of the utmost importance for intensive aquaculture. Digestion and absorption of nutrients depends on the activity of the digestive enzymes, in particular those located in the brush border membrane of enterocytes, which are responsible for the final stages of breaking down and absorption of nutrients. In the present study, the substitution of fish meal by lupin or rapeseed meal in the diet was evaluated on gilthead sea bream (Sparus aurata) and goldfish (Carassius auratus). The objectives were to compare the activities of intestinal brush border enzymes in both species fed the control and experimental diets. When gilthead sea bream were fed the vegetable diets, significantly lower activities compared to the control group were observed for alkaline phosphatase and $y$-glutamyl transpeptidase, but these differences were not significant in goldfish. Maltase activity was found decreased in the group fed lupin meal, both in sea bream and in goldfish. However, in spite of these differences in enzyme activities, growth characteristics of the fishes were similar with the three diets. It seemed that both fish were able to adapt to partial substitution of fishmeal, but it remains to investigate the mechanism for compensating the decrease in specific enzymatic activity in the enterocytes of carnivorous gilthead sea bream.
\end{abstract}

Keywords: Sparus aurata, Carassius auratus, fish meal replacement, brush border membrane, digestive enzymes, alkaline phosphatase, aminopeptidase N, maltase, glutamyl transpeptidase 


\section{Introduction}

Marine fish aquaculture is a worldwide expanding industry, in which production has been concentrated in Europe on species such as gilthead sea bream, Sparus aurata L., and sea bass, Dicentrarchus labrax (L.) (Chabrillón et al., 2005). Limited supplies and the high cost of fish meal have forced fish nutritionists to search for alternative protein sources. Plant-derived protein sources, such as soybeans and lupin, are considered as interesting alternatives for fish meal, because they are widely available and do not conflict with human food security interests (Leenhouwers et al., 2006). Such sustainable composition of diets of high nutritional value is of extremely important for intensive aquaculture. The formulation of diets is usually based on the digestibility data of the dietary nutrients used and this information is of great importance for assessing the nutritional value and quality of these nutrients. However, the digestion and absorption of the nutrients directly depend on the activity of the digestive enzymes, in particular those located in the brush border section of the intestine, which are responsible for the final stages of breaking down and assimilation of food (Fountoulaki et al., 2005). Fish meal has been a major ingredient in compound feeds for $S$. aurata, but alternative sources of protein are being used increasingly as fish meal availability decreases and prices increase. The vast majority of these alternative ingredients are plant-based, notably soybean products. The use of such ingredients introduces components which are known to affect digestive physiology along the digestive tract and which reduce the digestibility and utilization of the nutrient (Deguara et al., 2003).

Digestion and absorption of nutrients depends on the activity of the digestive enzymes, in particular those located in the brush border section of the intestine, which are responsible for the final stages of breaking down and assimilation of the food (Klein et al., 1998). Much research has been conducted in the last two decades to study the digestive ability and specific nutritional requirements of fish larvae and juveniles (Cahu \& Zambonino Infante, 2001). Intestinal epithelium is considered to be the structure most likely associated with the terminal digestion of luminal peptides in vertebrates. Intestinal peptide hydrolases are found in two main sub-cellular locations, the cytosol and the brush border membrane of enterocytes (Zambonino Infante \& Cahu, 2007). When enterocyte maturation occurs in fish larvae, the activity of the cytosolic enzymes decrease concurrently with the development of several enzymes like alkaline phosphatase, maltase, $\gamma$-glutamyl-transpeptidase and aminopeptidase $\mathrm{N}$ located in the brush border membrane (Cahu \& Zambonino Infante, 1995; Ma et al., 2005). Alkaline phosphatase is a dominant enzyme of the intestinal brush border, and is often used as a marker of the intestinal integrity (Wahnon et al., 1991). Its activity is increased in a few hours in presence of its substrates. The functional significance of this enzyme is far to be fully understood, however it hydrolyzes phosphoester bounds in various organic compounds like proteins, lipids, and carbohydrates (Nikawa et al., 1998). Maltase is a disaccharidase which activity is rapidly (in less than $24 \mathrm{H}$ ) altered by the presence of disaccharides in the intestinal lumen (Santos et al., 1992). $\gamma$-glutamyltranspeptidase and aminopeptidase $\mathrm{N}$ are among the major enzymes of the intestinal microvilli, and play an essential role in the final hydrolyze and assimilation of dietary proteins (Douglas et al. 1999). The activity of these two enzymes is greatly enhanced by intraluminal peptide nutrients (Sonoyama et al., 1994).

The adaptive responses of these enzyme activities occur within hours and are particularly well recommended for assessing the impact on the intestinal function and integrity of non-conventional protein sources.

The present study evaluated the effect of partial substitution of fish meal by lupin or rapeseed meals in the diet to evaluate growth response and activities of intestinal brush border enzymes in two different model species having different feeding behaviours and trophic levels: (1) a marine temperate fish, gilthead sea bream (Sparus aurata), with a short digestive tract, and (2) a fresh warm-water species, goldfish (Carassius auratus), having a long relative intestine length.

\section{Materials and methods}

\subsection{Animals and general rearing conditions}

Gilthead sea bream (Sparus aurata) were provided by Ferme Marine de Douhet (FMD, La Brée les Bains, France), and the experiment was conducted at the laboratory 'Adaptation, Reproduction et Nutrition des poissons' (ARN, Ifremer, Centre de Brest, France). The fish were distributed into two tanks (1000 I). They were supplied with running seawater at $18-20^{\circ} \mathrm{C}$, and $35 \mathrm{ppt}$ salinity. Photoperiod was maintained at 12-12 light/dark. After an adaptation period, the fish were distributed into 12 conical 
fiberglass tanks (60 I capacity; 40 individuals per tank). Until the start of the experiment, they were fed a commercial diet. The goldfish (Carassius auratus) were reared at the laboratory 'Nutrition, Métabolisme et Aquaculture' (INRA, Saint Pée-sur-Nivelle, France). Goldfish juveniles were distributed into 9 conical fiberglass tanks (60 I capacity; 30 individuals per tank). They were supplied with running freshwater at $23-25^{\circ} \mathrm{C}$. Photoperiod was maintained at $12-12$ light/dark.

\subsection{Experimental design}

The experiment lasted 30 days, during which the fish were fed one of the three diets, tested in quadruplicate for gilthead sea bream and in triplicate for goldfish. The experiments were intended to compare the effect of the partial substitution of fish meal with either rapeseed or lupin meal in isoproteic diets $(42 \%$ on a dry matter basis, Table 1$)$. The level of substitution with the single plant protein source was limited to $20 \%$ of the diet based on earlier studies, particularly with relevance to limit the levels of possible antinutritional factors in ingredients such as lupin (Burel et al. 1998; Glencross et al. 2003) or rapeseed meal (Burel and Kaushik, 2008). The diet with lupin meal was balanced with lysine, methionine and leucine. After 10 days of acclimation, the tanks were randomly allotted to the three experimental groups $F, L$ and $R$ which were fed the fish meal diet, the rapeseed diet, and the lupin diet, respectively. The fish were fed twice a day, at $2 \%$ of daily ration on body weight basis. No mortality was observed during the experiment. The fish were weighed under anesthesia with benzocaine at start, and by the end of the 30 days of experiment. During the two experiments, the gilthead sea bream grew from $18.8 \pm 2.1 \mathrm{~g}$ to $33.8 \pm 5.5 \mathrm{~g}$, and the goldfish grew from $21.5 \pm 0.3 \mathrm{~g}$ to $29.2 \pm 7.3 \mathrm{~g}$. No significant difference was observed between the mean weights of the experimental groups (Table 2).

\subsection{Sampling and dissection of gilthead sea bream and goldfish}

The fish were sampled in each tank by the end of the experiments, after four weeks of experimental feeding. The fish were euthanized with 2-phenoxythanol, the corporal surface was disinfected with ethanol (70\%), and the abdominal cavity was opened. The mucosa of the digestive tract were collected by scrapping the anterior intestine for further purification of brush border membranes (see below) for enzymatic determinations.

\subsection{Enzymatic determinations}

The intestinal mucosa was homogenized to purify brush border membranes (BBM) according to a method described by Crane et al. (1979). The intestinal mucosa was homogenized with a homogenizer (Polytron, PT-MR 2100) at maximum speed for $30 \mathrm{~s}$. Then, $1 \mathrm{ml}$ homogenate was collected, $\mathrm{CaCl}_{2}$ added, and sample first centrifuged at $9,000 \times \mathrm{g}$ for $10 \mathrm{~min}$, and supernatant centrifuged again at 3,400 $\times g$ for 20 min. The pellet was resuspended in Tris-Hepes buffer and was used for enzymes assays. The BBM enzymes aminopeptidase $N(A N)$, maltase, alkaline phosphatase (AP) and y-GT (y-Glutamyl transpeptidase) were assayed according to Maroux et al. (1973), Dahlqvist (1970), Bessey et al. (1946), and Meister et al. (1981) respectively. Total soluble proteins were determined according to Bradford (1976) using bovine serum albumin (Sigma Chemical Co., St. Louis, USA) as standard. Enzyme activities were expressed as specific activity, i.e. $\mu$ moles of substrate hydrolyzed/min per mg of total protein.

\subsection{Statistical analysis}

The results were given as mean \pm S.E. All data were analyzed by one-way analysis of variance (ANOVA) followed by Tukey's test method, SigmaStat®2.0. The differences were considered significant at $P<0.05$. 


\section{Results}

The diets were did not affect growth in both species. In gilthead sea bream, the mean weight doubled during the month of experiment, from 19 to $36 \mathrm{~g}$, without significant difference between groups. Ornamental goldfish, which were selected for slow growth, had their mean weight increased only from 22 to $29 \mathrm{~g}$ during the experiment. No mortality of fish was observed.

The activities of the intestinal enzymes AP, AN, $y-G T$ and maltase, assayed in purified intestinal BBM of gilthead sea bream and goldfish, are presented in Figs. 1 and 2, respectively. The purification factor was 5 to 8 for the AP, i.e., enzymatic activity was 5 to 8 times higher in purified membranes than in homogenates. In sea bream, there was a general trend to observe higher activities in the group fed the control fishmeal diet compared to the other two groups, but this difference was fully significant only with AP and $\mathrm{Y}-\mathrm{GT}$. The activity of maltase was significantly lower in the group fed lupin. The AN activity was not significantly different between groups. In goldfish, the activities were generally not significantly different, but maltase activity in the group fed lupin was lower than in the control group.

\section{Discussion}

The experiment confirmed that the replacement of fish meal was possible in large proportion in the diet of gilthead sea bream, without detrimental effect on growth, as already showed by several authors (Pereira and Oliva-Teles, 2002; Gómez-Requeni et al., 2003, 2004; Sitjà-Bobadilla et al., 2005; Dias et al., 2009). However, Kissil et al. (2000) observed a reduction of feed intake with high level of dietary rapeseed meal. Robaina et al. (1995) noted a decrease in intestinal trypsin activity due to dietary lupin meal, even if protein digestibility was not degraded in the end. A similar effect was observed on intestinal BBM enzymes in the present experiment.

Most of the intestinal enzymes involved in the final step of the digestive process are located in the brush border membranes of enterocytes. These enzymes, such as alkaline phosphatase, $\mathrm{v}$-glutamyl transpeptidase, $\mathrm{N}$-aminopeptidase, and maltase, are detected very early during larval development (Cahu and Zambonino Infante, 2001). A vast range of BBM enzymes associated with high enzymatic activity reveals an adequate differentiation and proliferation of intestinal cells, and reflects the nutritional status of the animals (Cahu et al., 2000; Zambonino Infante and Cahu, 2001). The knowledge of how different feed ingredients may affect enzyme activity is important, and this would provide information on if and how the choice of ingredients in feed formulations could allow a better efficiency of digestive enzymes (Deguara et al., 2003).

Alkaline phosphatase is found primarily in cell membranes where active transport takes place and it is considered as a general marker of nutrient absorption. The activity of alkaline phosphatase is often used to evaluate intestinal membrane function and integrity since this enzyme is an integral enzyme known to be intimately associated with the hydrophobic core of the intestinal microvillus membrane, in contrast to many others enzymes of the intestinal microvillus membrane such as maltase, aminopeptidase $\mathrm{N}$, which are extrinsic enzymes, the function of which does not seem to be intimately related to the membrane structure (Wahnon et al. 1992). The activity of all these enzymes is greatly modulated by the intraluminal presence of their dietary substrates, and it has been extensively shown that the adaptive response of these enzymes occurs within hours (Kimura et al., 1978; Cézard et al., 1983)

In the present study, the higher alkaline phosphatase activity found in sea bream fed herring diet is likely a consequence of the high content in phoshoproteins generally found in fish meals compared to vegetable meals. However, the higher activities found in this group for the other intestinal enzymes, that could not have been induced by higher content in specific substrates, strongly suggested an intestinal villi and microvilli better developed in sea bream fed the herring diet compared to fish fed the plant-based diet even though no significant effect was noted on growth. A possible explanation could be that this decrease in enzyme activity has been compensated by an increase in the intestine length, as already observed in sea bream fed plant based diets (Santigosa et al., 2008). Then, the specific activities of these enzymes were significantly decreased in intestinal BBM of sea bream fed the plant protein sources, but this did not necessarily resulted in a decrease of nutrient absorption. There was indication about a possible concomitant increase of the competent membrane surface in intestinal villi (Omnes et al., in preparation), besides the increase in intestinal length observed by Santigosa et al. (2008). 
Goldfish are omnivorous, and the species might consider as less sensitive than sea bream to the introduction of vegetable feedstuffs. Xie et al. (2001) fed gibel carp, a subspecies of goldfish, with a high level of dietary rapeseed meal, and they noted a feeding rate higher than in the control group fed a fishmeal diet. However, growth and dry matter digestibility of the rapeseed diet were significantly lower than in the control group. In the present study on goldfish, growth and the activity of most BBM enzymes did not seem affected by the diets. Only the specific activity of maltase appeared depressed by dietary lupin, both in goldfish, and in gilthead sea bream. This might be related to the carbohydrate content of lupin meal, which is mostly rich in non-starch polysaccharides (Bach Knudsen, 1997). However, the starch content of the rapeseed diet was even lower, while the maltase activity was not significantly affected by this diet. A possible interaction with digestive microbiota should be explored, since the lupin diet had a marked effect on foregut microbial diversity (Silva et al., in preparation).

In conclusion, the supply of plant protein sources influenced some digestive enzyme activities of carnivorous gilthead sea bream, but growth was not affected. These results suggest that fish can adapt to the partial substitution of fish meal with sustainable vegetal meals in the diet. The mechanism behind such adaptation remains to be explored.

\section{Acknowledgments}

This study was supported by grant from the Fundação de Amparo à Pesquisa do Estado de Minas Gerais (FAPEMIG CBB 804/06), Coordenação de Aperfeiçoamento de Pessoal de Nível Superior (CAPES) (Brazil), IFREMER and INRA (French). We thank P. Quazuguel, J. Moriceau, E. Desbruyères and $C$. Huelvan for their technical assistance and D. Mazurais for your helpful.

\section{References}

Bach Knudsen, K. E., 1997. Carbohydrate and lignin contents of plant materials used in animal feeding. Anim. Feed Sci. Tech. 67, 319-358.

Bessey, O.A., Lowry, O.H., Brock, M.J., 1946. Rapid colouring method for determination of alkaline phosphatase in five cubic millimeters of serum. J. Biol. Chem. 164, 321-329.

Bradford, M.M., 1976. A rapid and sensitive method for the quantification of microgram quantities of protein utilizing the principle of protein-dye binding. Anal. Biochem. 72, 248-254.

Burel, C., Kaushik, S.J., 2008. Use of rapeseed/canola in diets of aquaculture species. In : Alternative protein sources in aquaculture diets, (C. Lim, C. Webster \& C-S. Lee, Eds), The Haworth Press, Inc, NY, USA, pp. 343-408.

Burel, C., Boujard, T., Corraze, G., Kaushik, S.J., Bœuf, G., Mol, K.A., Van der Geyten, S., Kuhn, E.R., 1998. Incorporation of high levels of extruded lupin in diets for rainbow trout : nutritional value and effect on thyroid status. Aquaculture, 163, 325-345.

Cahu, C.L., Zambonino Infante, J.L., 1994. Early weaning of sea bass (Dicentrarchus labrax) larvae with a compound diet: effect on digestive enzymes. Comp. Biochem. Physiol. 109, 213-222.

Cahu, C.L., Zambonino Infante, J.L., 1995. Effect of the molecular form of dietary nitrogen supply in sea bass larvae: response of pancreatic and intestinal peptidases. Fish Physiol. Biochem. 14, 2009-214. 
Cahu, C.L., Zambonino Infante, J.L., Corraze, G., Coves, D., 2000. Dietary lipid level affects fatty acid composition and hydrolase activity of intestinal brush border membrane in sea bass. Fish Physiol. Biochem. 23, 165-172.

Cahu, C.L., Zambonino Infante, J.L., 2001. Substitution of live food by formulated diets in marine fish larvae. Aquaculture 200, 161-180.

Cézard, J.P., Broyart, J.P., Cuisinier-Gleizes, P., Mathieu, H., 1983. Sucrase-isomaltase regulation by dietary sucrose in the rat. Gastroenterology $84,18-25$.

Chabrillón, M., Rico, R.M., Balebona, M.C., Moriñigo, M.A., 2005. Adhesion to sole, Solea senegalensis Kaup, mucus of microorganisms isolated fish, and their interaction with Photobacterium damselae subsp. piscicida. J. Fish Dis. 28, 229-237.

Crane, R.K., Boge, G., Rigal, A., 1979. Isolation of brush border membranes in vesicular form from the intestinal spiral valve of the small dogfish Scyliorhinus canicula. Biochim. Biophys. Acta 554, 264-267.

Dahlqvist, A., 1970. Assay of intestinal dissacharidase. Enzym. Biol. Clin. 11, 52-66.

Deguara, S., Jauncey, K., Agius, C., 2003. Enzyme activities and pH variations in the digestive tract of gilthead sea bream. J. Fish Biol. 62, 1033-1043.

Dias, J., Conceição, L. E. C., Ribeiro, A. R., Borges, P., Valente, L. M. P. , Dinis, M. T., 2009. Practical diet with low fish-derived protein is able to sustain growth performance in gilthead sea bream (Sparus aurata) during the grow-out phase. Aquaculture 293, 255-262.

Douglas, S.E., Gallant, J.W., Bullerwell, C.E., 1999. Molecular investigation of aminopeptidase N expression in the winter flounder, Pleuronectes americanus. J Appl Ichthyol 15, 80-86.

Fountoulaki, E., Alexis, M.N., Nengas, I., Venou, B., 2005. Effect of diet composition on nutrient digestibility and digestive enzyme levels of gilthead sea bream (Sparus aurata L.). Aquac. Res. 36, 1243-1251.

Glencross, B.D., Boujard., T., Kaushik, S.J., 2003. Influence of oligosaccharides on the digestibility of lupin meals when fed to rainbow trout, Oncorhynchus mykiss. Aquaculture 219: 703-713.

Gómez-Requeni, P., Mingarro, M., Kirchner, S., Calduch-Giner, J. A., Médale, F., Corraze, G., Panserat, S., Martin, S. A. M., Houlihan, D. F., Kaushik, S. J., Pérez-Sánchez, J., 2003. Effects of dietary amino acid profile on growth performance, key metabolic enzymes and somatotropic axis responsiveness of gilthead sea bream (Sparus aurata). Aquaculture 220, 749-767.

Gómez-Requeni, P., Mingarro, M., Calduch-Giner, J. A., Médale, F., Martin, S. A. M., Houlihan, D. F., Kaushik, S. J., Pérez-Sánchez, J., 2004. Protein growth performance, amino acid utilisation and somatotropic axis responsiveness to fish meal replacement by plant protein sources in gilthead sea bream (Sparus aurata). Aquaculture 232, 493-510. 
Kissil, G. W., Lupatsch, I., Higgs, D. A., Hardy, R. W., 2000. Dietary substitution of soy and rapeseed protein concentrates for fish meal, and their effects on growth and nutrient utilization in gilthead sea bream Sparus aurata L. Aquac. Res. 31, 595-601.

Kimura, T., Seto, A., Yoshida, A., 1978. Effect of Diets on Intestinal Disaccharidase and Leucineaminopeptidase Activities in Refed Rats. J. Nutr. 108, 1087-1097.

Klein, S., Cohn, S.M., Alpers, D.H., 1998. The alimentary tract in nutrition. In: Shils, M.E., Olson, A.J., Shike, M., Ross, A.C. (Eds.), Modern Nutrition in Health and Disease, pp. 605-630.

Leenhouwers, J.I., Adjei-Boateng, D., Verreth, J.A.J., Schrama, J.W., 2006. Digesta viscosity, nutrient digestibility and organ weights in African catfish (Clarias gariepinus) fed diets supplemented with different levels of a soluble non-starch polysaccharide. Aquac. Nutr. 12, 111-116.

Ma, H., Cahu, C., Zambonino, J., Yu, H., Duan, Q., Le Gall, M.M., Mai, K., 2005. Activities of selected digestive enzymes during larval development of large yellow croaker (Pseudosciaena crocea). Aquaculture 245, 239-248.

Maroux, S., Louvard, D., Baratti, J., 1973. The aminopeptidase from hog-intestinal brush border. Biochim. Biophys. Acta 321, 282-295.

Meister, A., Tate, S.S., Griffith, O.W. 1981. Methods Enzymol. 77, 237-253.

Nikawa, T., Rokutan, K., Nanba, K., Tokuoka, K., Teshima, S., Engle, M.J., Alpers, D.H., Kishi, K., 1998. Vitamin A Up-Regulates Expression of Bone-Type Alkaline Phosphatase in Rat Small Intestinal Crypt Cell Line and Fetal Rat Small Intestine. J. Nutr. 128, 1869-1877.

Pereira, T. G., Oliva-Teles, A., 2002. Preliminary evaluation of pea seed meal in diets for gilthead sea bream (Sparus aurata) juveniles. Aquac. Res. 33, 1183-1189.

Robaina, L., Izquierdo, M. S., Moyano, F. J., Socorro, J., Vergara, J. M., Montero, D., FernándezPalacios, H., 1995. Soybean and lupin seed meals as protein sources in diets for gilthead sea bream (Sparus aurata): nutritional and histological implications. Aquaculture 130, 219-233.

Santigosa, E., Sánchez, J., Médale, F., Kaushik, S., Pérez-Sánchez, J., Gallardo, M. A., 2008. Modifications of digestive enzymes in trout (Oncorhynchus mykiss) and sea bream (Sparus aurata) in response to dietary fish meal replacement by plant protein sources. Aquaculture $282,68-74$

Santos, B.K.S.-D., Goda, T., Koldovsky, O., 1992. Dietary-induced increases of disaccharidase activities in rat jejunum. Brit J Nutr 67, 267-278.

Sitjà-Bobadilla, A., Peña-Llopis, S., Gómez-Requeni, P., Médale, F., Kaushik, S., Pérez-Sánchez, J., 2005. Effect of fish meal replacement by plant protein sources on non-specific defence mechanisms and oxidative stress in gilthead sea bream (Sparus aurata). Aquaculture 249, 387-400.

Sonoyama, K., Kiriyama, S., Niki, R., 1994. Effect of dietary protein level on intestinal aminopeptidase activity and mRNA level in rats. The Journal of Nutritional Biochemistry 5, 291-297. 
Xie, S., Zhu, X., Cui, Y., Yang, Y., 2001. Utilization of several plant proteins by gibel carp (Carassius auratus gibelio). J. Appl. Ichthyol. 17, 70-76.

Wahnon, R., Cogan, U., Mokady, S., 1992. Dietary fish oil modulates the alkaline phosphatase activity and not the fluidity of rat intestinal microvillus membrane. J. Nutr. 122, 1077-1084.

Zambonino, J.L., Cahu, C.L., 2001. Ontogeny of the gastrointestinal tract of marine fish larvae. Comp. Biochem. Physiol. 130C, 477-487.

Zambonino, J.L., Cahu, C.L., 2007. Dietary modulation of some digestive enzymes and metabolic processes in development marine fish: Applications to diet formulation. Aquaculture 268, 98105.

Omnes, M.H., Silva, F.C.P., Desbruyères, E., Le Gall, M.M., Moriceau, J., Le Ven, A., Severe, A., Aguirre, P., Gatesoupe, F.J., Kaushik, S.J. (2010) in preparation.

Silva, F.C.P., Nicoli, J.R., Zambonino-Infante, J.L., Kaushik, S., Gatesoupe, F.J. (2010) in preparation. 
Table 1. Ingredients and chemical composition of the experimental diets

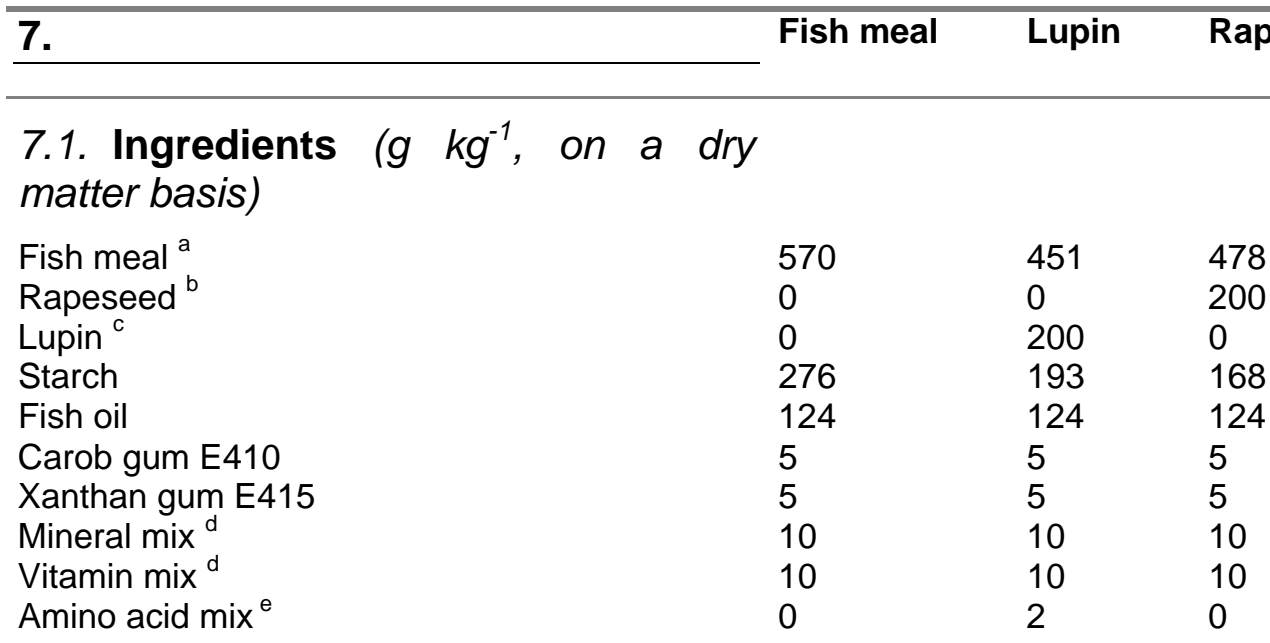

\section{Analysed composition}

Dry matter (DM, \%)

97.8

$94.8 \quad 97.6$

Crude protein (\% DM)

45.4

45.5

Crude fat (\% DM)

19.0

20.5

18.6

Aminoacid composition (\% crude protein) ${ }^{\dagger}$

Arginine
Histidine
Isoleucine
Leucine
Lysine
Methionine+cystine
Phenylalanine+tyrosine
Threonine
Tryptophane
Valine

$\begin{array}{lll}4.8 & 4.6 & 5.0\end{array}$

\footnotetext{
${ }^{\text {a }}$ Norse-LT 94 supplied by La Lorientaise, Lorient, France. The amounts were adjusted to obtain isoproteic diets ( $42 \%$, dry matter basis).

${ }^{\mathrm{b}}$ SAIPOL, Grand Couronne, France.

' Lup'Ingredients, Martigne Ferchaux, France.

${ }^{\mathrm{d}}$ According to Cahu et al. (1999).

${ }^{\mathrm{e}}$ leucine $36,8 \%$; lysine $31,6 \%$, methionine $31,6 \%$

${ }^{f}$ computed after data from raw feedstuffs
} 
Table 2 Initial and final mean weights of seabream and goldfish (in g, \pm standard deviation). At the end of the experiments, the differences were not significant.

\begin{tabular}{lccc}
\hline Diets & $\mathrm{F}$ & $\mathrm{R}$ & $\mathrm{L}$ \\
\hline Gilthead seabream & & & \\
Initial weight $(\mathrm{g})$ & $18.80 \pm 2.10$ & $18.80 \pm 2.10$ & $18.80 \pm 2.10$ \\
Final fish weight $(\mathrm{g})$ & $31.90 \pm 4.11$ & $35.20 \pm 6.63$ & $34.20 \pm 5.65$ \\
& & & \\
\hline Goldfish & & & \\
Initial weight (g) & $21.50 \pm 0.30$ & $21.50 \pm 0.30$ & $21.50 \pm 0.30$ \\
Final fish weight (g) & $27.72 \pm 6.44$ & $33.44 \pm 10.09$ & $26.53 \pm 5.51$ \\
& & & \\
\hline
\end{tabular}



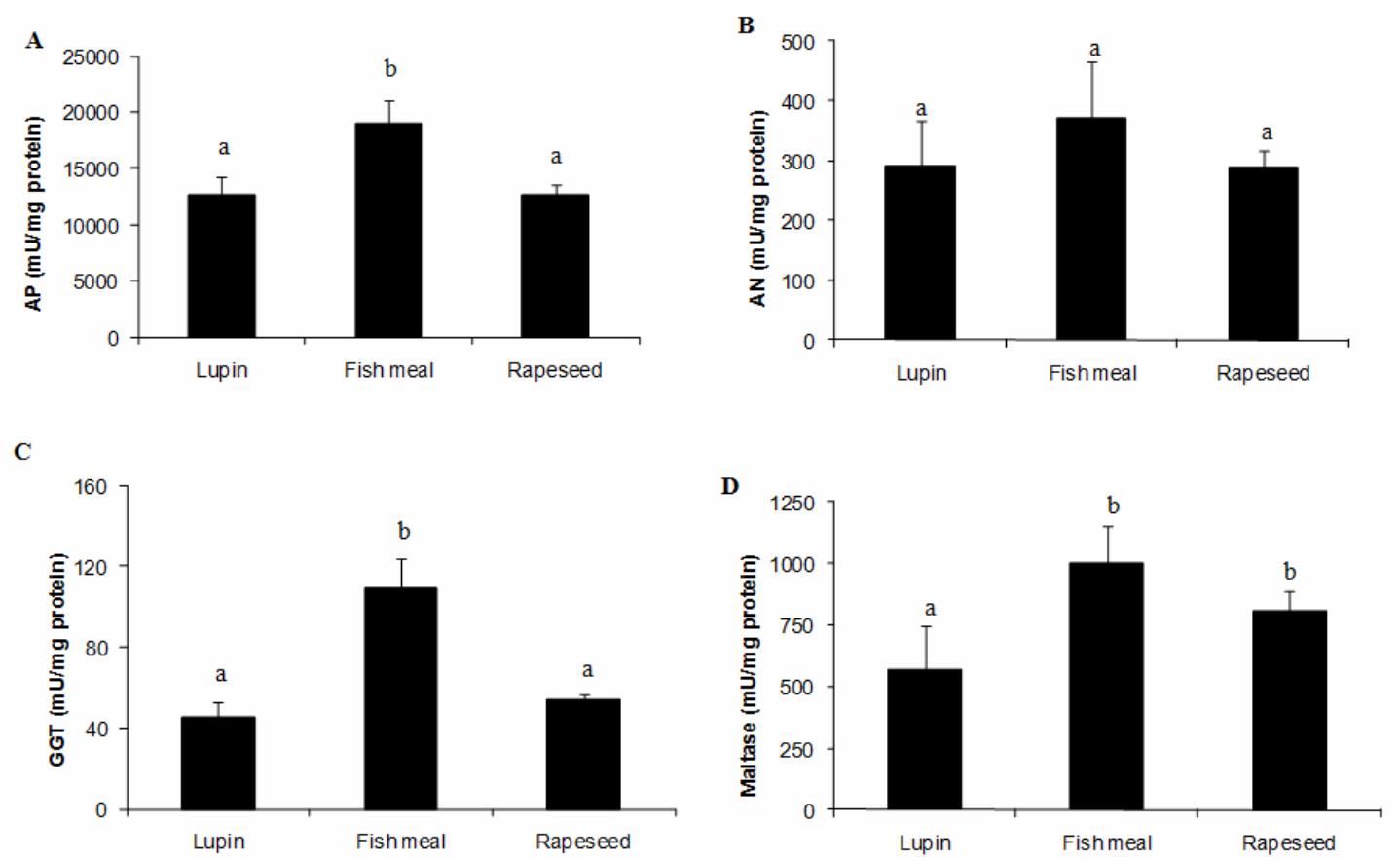

Figure 1. Specific activity ( $\mathrm{mU} \mathrm{min}{ }^{-1}$ protein $\left.{ }^{-1}\right)$ of (A) alkaline phosphatase (AP), (B) aminopeptidase $\mathrm{N}$ (AN), (C) Y-glutamyl transpeptidase, and (D) maltase in the purified intestinal brush border membrane of juvenile gilthead sea bream (S. aurata), fed the three different diets. Means \pm S.D. with different superscript are significantly different $(p<0.05)$. 
$\mathbf{A}$
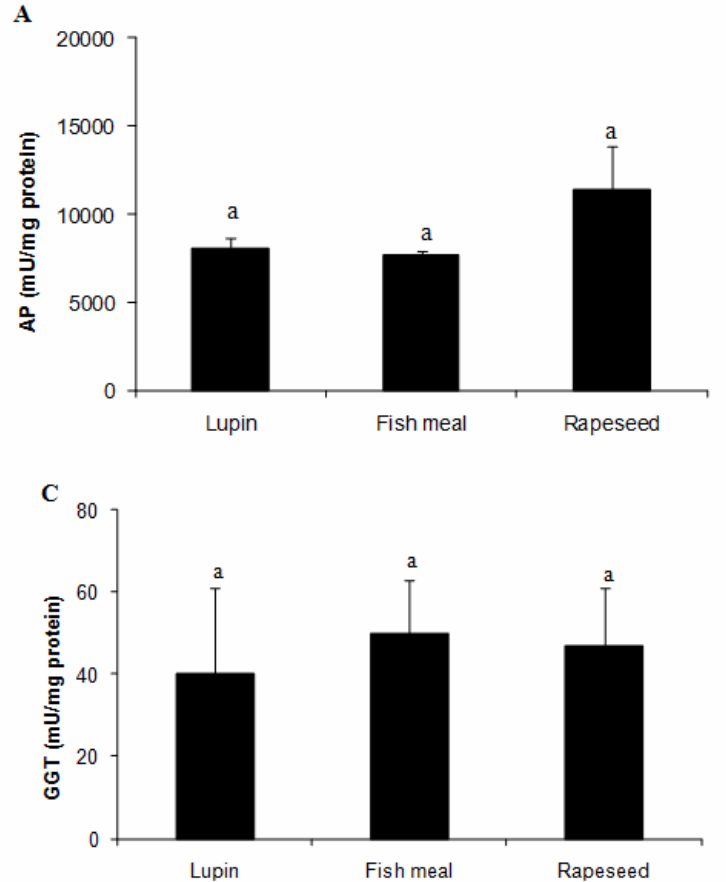
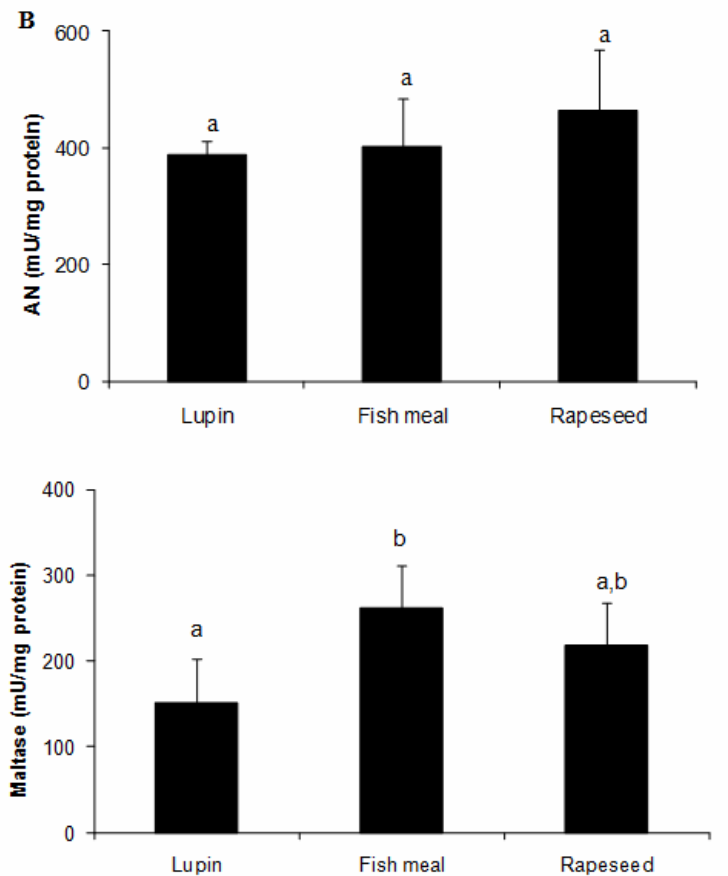

Figure 2. Specific activity $\left(\mathrm{mU} \mathrm{min} \mathrm{m}^{-1}\right.$ protein $\left.{ }^{-1}\right)$ of $(\mathrm{A})$ alkaline phosphatase (AP), (B) aminopeptidase $\mathrm{N}$ (AN), (C) Y-glutamyl transpeptidase, and (D) maltase in the purified intestinal brush border membrane of juvenile goldfish (C. auratus), fed the three different diets. Means \pm S.D. with different superscript are significantly different $(p<0.05)$. 